\title{
37. DIAGENESIS OF SILICA, ZEOLITES, AND PHYLLOSILICATES AT SITES 397 AND 398
}

\author{
Volkher Riech, Bundesanstalt für Geowissenschaften und Rohstoffe (Federal Institute for Geosciences and \\ Natural Resources), D 3000 Hannover 51, West Germany
}

\begin{abstract}
To determine silica, carbonate, and clay mineral diagenesis, sediment samples from DSDP Sites 397 and 398 (eastern North Atlantic continental margin) were studied by X-ray diffraction, light microscopy, and scanning electron microscopy.

The development of silica diagenesis at Site 397 is predetermined by the original distribution of silica-contributing components. Opaline skeletons (upwelling conditions) favor the formation of clinoptilolite and opal-CT (i.e., disordered low-temperature cristobalite/ tridymite); volcanogenic components favor the precipitation of authigenic phillipsite and montmorillonite. The latter two minerals in Pliocene ash layers are the result of rapid diagenetic processes occurring at about 300 meters burial depth. A sudden increase of diagenesis is marked by intensive calcite cementation at about 700 meters, coinciding with the first occurrences of clinoptilolite and opal-CT lepispheres and the transformation of amorphous siliceous skeletons into crystallized opal-CT.

Silica: At Site 397, the neoformation of opal-CT occurs mainly in mudstones between 700 and 1300 meters (early-middle Miocene) and is closely associated with the precipitation of clinoptilolite. Silicified sediments and porcelanites occur in the lowermost early Miocene $(1150$ to $1300 \mathrm{~m})$ and are probably not reworked from pre-Miocene strata. Comparisons with other DSDP sites off Northwest Africa show that the youngest porcelanites in this continental margin setting always occur in clay-rich lower Miocene sediments. This is surprising because, according to other authors, $\mathrm{CaCO}_{3}$ should accelerate the opal-CT formation in deep-sea sediments. The autochthonous Miocene porcelanites at Site 397 consist entirely of the metastable opal-CT phase and still contain a certain "diagenetic potential." At Site 398, however, similar silicified sediments of Aptian age, also at 1300 meters, are in a transitional stage to mature quartz-cherts indicated by an opal-CT matrix with quartz nuclei.

Zeolites: At Site 397, the dominant zeolites (clinoptilolite and phillipsite) show a distinct distribution pattern controlled by facies, burial depth, and diagenetical alteration or dissolution stage of the parent material. Phillipsite, associated with authigenic montmorillonite, occurs only in layers with altered volcanic glass at 310 to 800 meters, whereas clinoptilolite is restricted to more deeply buried sediments with some dissolved siliceous remains. Intraparticle porosity by microfossils, e.g., foraminiferal chambers, is a further prerequisite for the nucleation of clinoptilolite, whereas phillipsite also replaces the matrix. Horizons with fresh glass or opal-CT preserved skeletons never contain significant amounts of zeolites.

Authigenic phyllosilicates: Although smectite is mainly of detrital origin in the Miocene sediments of Site 397, authigenic montmorillonite occurs locally as an alteration product of volcanogenic sediments. In addition, a genuine montmorillonite "cement" has formed in foraminiferal chambers and wall pores, partly inside palisades of calcite cement. In other cases, phyllosilicates even replace calcitic echinoid spines.

Diagenetic relationships: The silica-rich clinoptilolite can form either during an increase of the silica concentration in the pore waters before opal-CT or during a decrease of this concentration after opal-CT. Post-early-diagenetic calcite cement always formed earlier than clinoptilolite. The precipitation of $\mathrm{CaCO}_{3}$ probably lowered the carbonate ion activity in the pore solutions, improving the conditions for the authigenesis of silicates. In the middle Miocene tuffaceous sandstones, phillipsite represents an intermediate phase in the precipitation sequence montmorillonite-phillipsite-calcite cement.
\end{abstract}

\section{INTRODUCTION}

The major scientific objectives of Leg 47 aimed at understanding the stratigraphy and evolution of the passive continental margin off Northwest Africa. In addition, such deep and continuously cored wells are suitable for detecting the diagenetic history of the sedi- ments which is dependent on time, temperature, depth of burial, and facies. According to Schlanger and Douglas (1974), the "diagenetic potential" increases with growing content of diagenetically metastable sedimentary components. In this way, the paleoenvironmental condition (e.g., upwelling favoring siliceous organisms) control the subsequent lithification process 
and the formation of authigenic minerals (e.g., zeolites, porcelanites, and cherts).

This investigation emphasized the silica diagenesis ( silica, zeolites, and clay minerals), especially from Site 397 , and demonstrated its relationship to the development of calcite cementation. Because of the 100 million year hiatus between Hauterivian and early Miocene at Site 397 , the generally chert-bearing Upper Cretaceous and Eocene sediments are missing. However, accessory disordered low-temperature "cristobalite" (i.e., opalCT) and, in some cases, precursors of cherts (porcelanites) can be recognized in the lower Miocene section. Thus, we gained new information about the early diagenetic silicification of sediments, which can be compared with previously published results from the North Atlantic DSDP Legs 14, 41, and 43 (von Rad and Rösch, 1974; von Rad et al., 1978; Riech and von Rad, in press) and the data from Pacific DSDP Legs and from experiments (e.g., Keene, 1975; Stein and Kirkpatrick, 1976; Kastner et al., 1977).

Furthermore, it seems appropriate to compare the diagenetic evolution of the volcanogenic sediments at Site 397 (see also Schmincke and von Rad, this volume) with that in the remaining facies. We tried to answer the following questions: (1) To what extent is volcanogenic material an immediate silica source for formation of authigenic silica or cherts? (2) Does the distribution pattern of the main sedimentary zeolites (phillipsite and clinoptilolite) in Leg 47 sediments coincide with the recent DSDP results of Houghton et al. (in press) and Stonecipher (1976)? (3) Can an authigenic neoformation of phyllosilicates be detected besides the mainly detrital origin of the clay minerals (Chamley and d'Argoud, this volume)?

Although some aspects of carbonate diagenesis were investigated (cementation, $\mathrm{Fe}$ content in secondary calcite, dolomitization and $\mathrm{Ca} / \mathrm{Mg}$ ratios, and siderite in association with newly formed apatite), the results cannot be discussed in detail in this paper because of space limitations. The general trends are shown in Figures 1 and 2, and in the foldout diagram (foldout, back pocket, this volume), and briefly summarized in the Summary and Conclusions of the Site Report.

A suitable method of investigation is the combination of light and electron microscopy (Siemens Autoscan electron microscope, ETEC) with X-ray diffraction analysis of total or individual size fractions. In some cases, a concentration of silicates by acid treatment or heavy-liquid separation was necessary. The mineralogy of siliceous organisms was determined by measuring the refractive indexes (Cargille refractive index oils with successive increments of 0.01 ).

\section{SILICA DIAGENESIS}

\section{Siliceous Organisms}

Our examinations on the diagenesis of skeletal opal in comparatively deeply buried sediments should supplement the new research on preservation and dissolution of siliceous microfossils in surface sediments (Schrader, 1972; Hurd, 1973; Heath, 1974; Johnson, 1976).

Biogenic opal-A (i.e., X-ray amorphous opal; Jones and Segnit, 1971) is a metastable phase which frequently dissolves in the water column or surface sediments. The small percentage of opaline skeletons, preserved in the sedimentary record, are transformed into opal-CT and finally into stable quartz, as seen by scanning electron and light microscope investigations of radiolarians and sponge spicules from the eastern and western North Atlantic (von Rad et al., 1978; Riech and von Rad, in press). Even quartzified sponge spicules had a former opal-CT stage, proven by relic patterns of interpenetrating cristobalite-like crystal blades. These mineralogical results agree with the now relatively well-known genesis of deep-sea cherts and experiments dealing with the crystallization of silica from solutions or gels (Kastner et al., 1977; Mizutani, 1977): opal-CT is a frequent precursor of quartz.

In general, the determination of refractive indexes differentiates opal-A and opal-CT (see also Hurd and Theyer, in press). We determined $n=1.40$ to 1.455 for opal-A, and $n=1.46$ to 1.49 for opal-CT. Extremely low indexes $(n=1.36)$ of some opal-A radiolarians in Quaternary and Pliocene volcanic glass-bearing layers are unexplained. Also, higher values $(n>$ 1.50) in a few lower Miocene samples of Site 397 are difficult to interpret. Goll and Bjørklund $(1972,1074)$ described recent radiolarians of the equatorial and South Atlantic with very high refractive indexes (up to 1.53 ). If these values are representative, it would complicate the optical opal-A/CT determination of siliceous organisms considerably. According to these authors, the abnormal refractive indexes could be due to specific physical-chemical water conditions in the habitat of these radiolarians. Our high indexes might also be due to contamination (e.g., adhering clay particles) on the surface of the fossil skeletons.

Because of the paucity of siliceous organisms in the middle and upper Miocene of Site 397, the presence of

Figure 1. Major diagenetic trends at Sites 397 and 398 concerning siliceous organisms, formation of opal-CT, zeolite, dolomite/siderite, silicification of sediments and $\mathrm{CaCO}_{3}$-cementation in foraminifers and sandstones. Frequency of skeletal opal and zeolites at Site 398 after Shipboard Reports. Explanation of symbols: 1 = opal-CT in nonvolcanogenic sediments ( $a=$ weak, $b=$ strong); $2=$ clinoptilolite in non-volcanogenic sediments $(a=$ weak, $b=$ strong); $3=\mathrm{CaCO}_{3}$-cementation in foraminifers and sandstones ( $a=$ strong, $b=$ weak); $4=$ alternation of $\mathrm{CaCO}_{3}$-and zeolite cementation ( $r=$ replacement calcite in tuffaceous sandstones); $5=$ opal-CT in volcanogenic facies (core no. in brackets); $6=$ phillipsite in altered vitric ashes and tuffs; $7=$ zeolite in altered tuffaceous sandstones; 8 = silicified sediments to porcelanites (probably autochthonous); $9=$ definite allochthonous cherts; $10=$ significant formation of carbonate rhombs. Lithological symbols as in core summaries and in foldout diagram. 


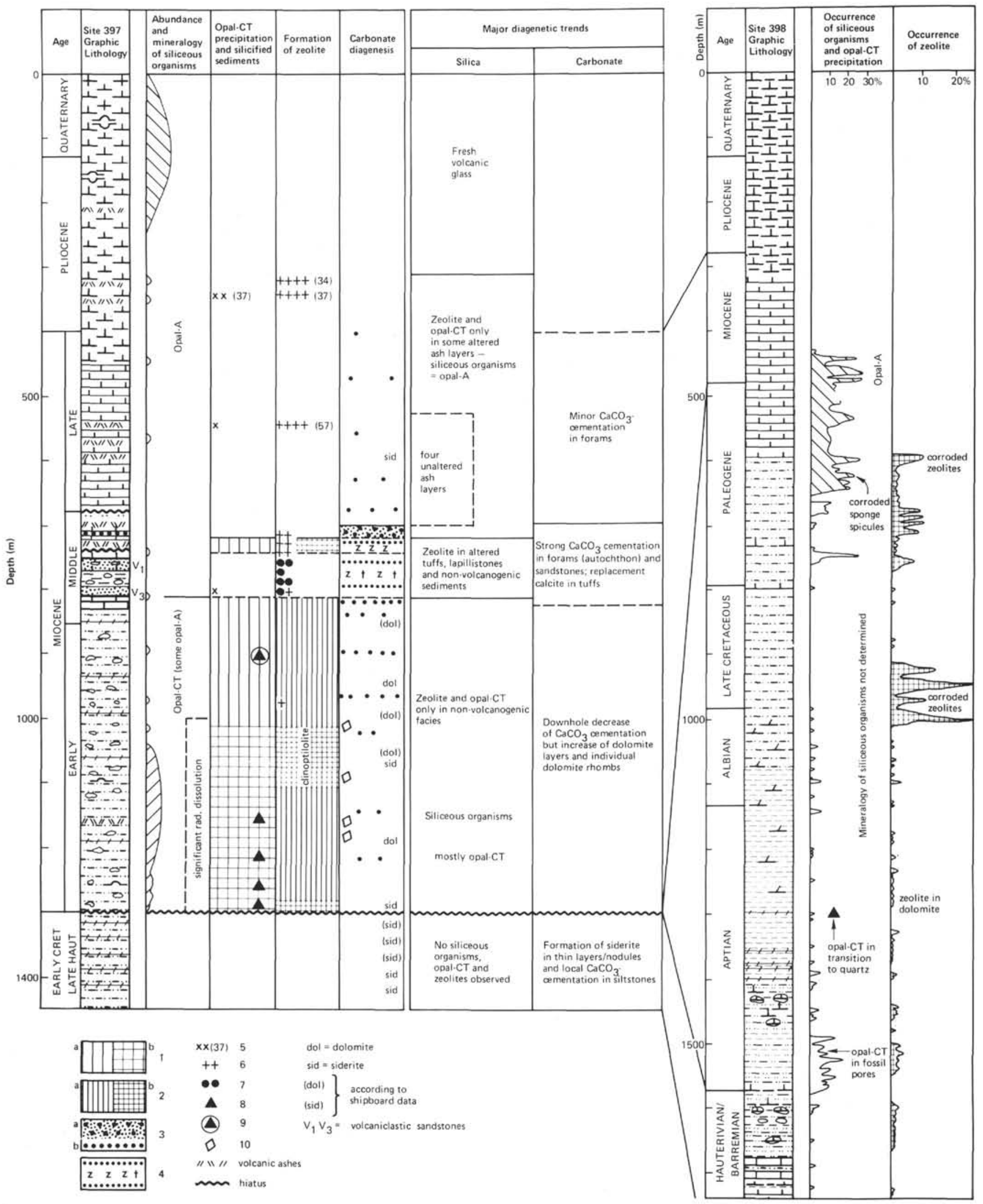



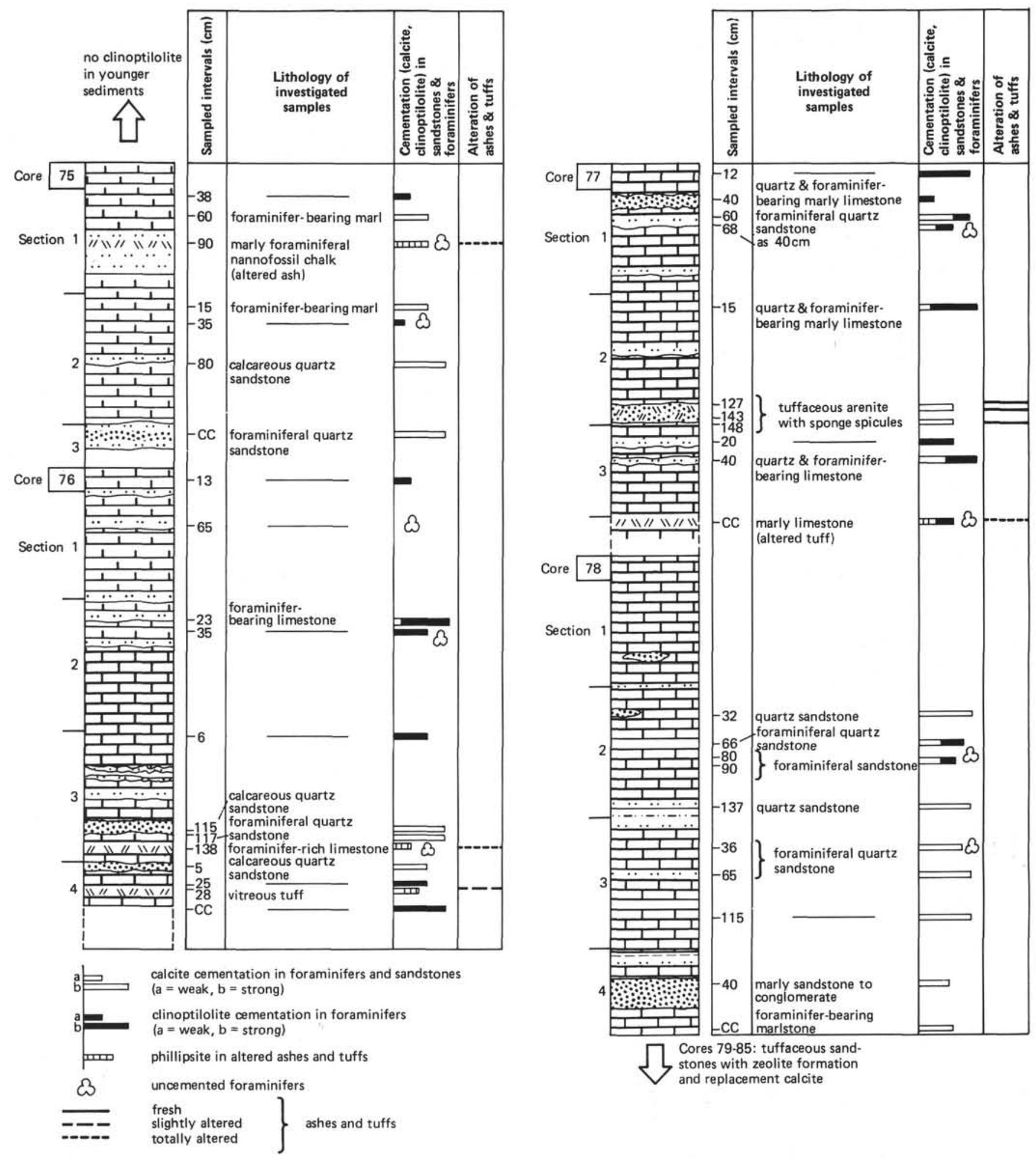

Figure 2. Calcite and zeolite cementation in sandstones or foraminiferal chambers and the alteration of ashes and tuffs in Cores 397-75 to 78. Different pore water levels result in alternating calcite or zeolite cementation (they may also occur together). The main zeolite occurrences (clinoptilolite) are restricted to non-volcanogenic sediments, whereas the phillipsite-rich horizons represent only altered ash layers. 
sponge spicules in Core 77 (Figure 2) is worth mentioning. The spicules are preserved as opal-A and embedded in a strongly cemented (calcite) tuffaceous arenite (debris flow?) which also contains sand-sized quartz, volcanic glass, and calcareous skeletals of shallow-water organisms.

It is impossible to decide whether the good preservation of the biogenic opal is influenced by the admixture of glass (increased silica concentration in pore waters ?) or the decreased permeability (cementation).

At Site 398, mineralogically unaltered opaline organisms (Plate 1, Figures 3 through 6 ) extend down to at least 600 meters, into Eocene sediments; there are no determinations in older strata. At Site 397, however, middle to early Miocene opaline organisms ( 800 to $1300 \mathrm{~m}$ ) are transformed into opal-CT (Plate 2, Figures 1 and 2 ). These differences could be the result of (1) grain-by-grain downslope redeposition of older and therefore diagenetically more altered radiolarians at Site 397. This suggestion is favored by the mixed occurrences of opal-A, opal-CT, and quartz skeletons in Core 397A-23. On the other hand, the reason for these differences could be (2) deeper burial at Site 397, enhancing the diagenesis of siliceous organisms.

In the sediments investigated from two sites of Leg 43 , the first radiolarians transformed into opal-CT are associated with Eocene porcelanites and occur at burial depths of 220 or 500 meters (Riech and von Rad, in press).

The transition of opal-A to opal-CT organisms at Site 397 coincides approximately with the change from the predominantly allochthonous Unit 4 strata to the autochthonous sediments of Unit 3 at 800 meters. But the results of Leg 43 and Leg 47A are in agreement, because the opal-A/CT transformation of siliceous skeletons always takes place at about the same depth, where the first opal-CT lepispheres (Plate 3, Figure 4) are precipitated in fossils and open pores of the matrix (Figure 1).

The postburial dissolution of incorporated siliceous skeletons is a prerequisite for the neoformation of authigenic silica and silicates. Below a burial depth of 1000 meters in the Miocene of Site 397, a discontinuous preservation pattern of radiolarian assemblages can be noticed: sediments with better-preserved opalCT skeletons alternate with layers containing only clayey radiolarian casts (Plate 2, Figures 3 and 4). The intensity of the dissolution of biogenic opal is sometimes positively correlated with the proportion of authigenic silica and clinoptilolite. This suggests an important causal relationship. In some cases, not only siliceous skeletons but also zeolites are etched. In the Eocene Cores 398D-22 and 23, the dissolution of opal-A preserved radiolarians and sponge spicules (Plate 1, Figures 3 through 6) coincides with the corrosion of clinoptilolite (Plate 3, Figure 6); apparently, this indicates silica-undersaturated interstitial waters active at a later stage or an earlier crystallization of clinoptilolite than at Site 397. A preceding selective dissolution of the more delicate diatoms (and radiolarians?) probably can explain the association of clinoptilolite and only slightly corroded, presumably less soluble radiolarian skeletons at Site 398. Johnson (1974) outlined a dissolution index method according to the relative susceptibility of opaline microfossils to dissolution. The association of resistant opal-A sponge spicules with clayey radiolarian casts, the skeletons of which are already dissolved (Sample 397A-66,CC), also agrees with Johnson's dissolution scheme. An exception is the preservation of delicate silicoflagellates in the early Miocene of Site 397 (Core 85).

\section{Precipitation of Accessory Opal-CT and the Silicification of Sediments}

In addition to the in-situ transformation of opaline skeletons to opal-CT, authigenic opal-CT is precipitated from silica-rich solutions in fossil chambers and other pores. The structures of these well-crystallized blades and spherical aggregates of platelets (i.e., "lepispheres," Plate 2, Figures 4 and 5; Plate 3, Figure 4) are described and discussed in Flörke et al. (1976).

The earliest opal-CT, identified at Site 397, occurs in a Pliocene ash layer (5 to $10 \%$ in Sample 397-37-4, $130 \mathrm{~cm}$; X-ray data table in the lithostratigraphy part of the Site Report). All the other volcanogenic sediments at this site, however, contain mainly montmorillonite and phillipsite as diagenetic products. Widespread occurrences of opal-CT, although in small quantities and frequently associated with clinoptilolite, can be noticed in the slightly biogenic opal-bearing mudstones of the early Miocene (Figure 1, 700 to $1300 \mathrm{~m}$ ). Because of increasing amounts of siliceous organisms in the earliest Miocene, the opal-CT precipitation is enhanced. Sporadically silicified mudstones and porcelanites (with more than $50 \%$ opal-CT) are formed between 1150 meters and 1300 meters. The fabric of a lens of procelanite in Core 397A-33, studied under the microscope at high magnification, consists of densely packed lepispheres. The foraminiferal tests are calcitic preserved, but chalcedony fills the chambers and indicates a secondary cementation phase after the opal-CT precipitation, but before the opal-CT $\rightarrow$ quartz transformation of the matrix. In calcareous sediments, the metastable "immature" porcelanites generally take less time (some million years) to be transformed into quartz-cherts than into clay-rich facies (von Rad et al., 1978). The clay-rich lower Miocene porcelanites from Site 397 need more time to undergo this evolution, whereas an Aptian porcelanite at Site 398 already contains many quartz nuclei in the matrix. Thus, the most important factors controlling the maturation sequence are time and depth (temperature), although the transformation rate can be strongly modified by the composition of the host sediments.

\section{Zeolites}

\section{General Remarks}

Recently, zeolites have received increasing attention in the investigation of deep-sea sediments. The results of Stonecipher (1976), who evaluated data from the DSDP Initial Reports, indicate a general correlation between phillipsite and argillaceous, volcanic, or sili- 
ceous sediments; low sedimentation rates; shallow burial depth; and young sediments. Conversely, clinoptilolite is associated with calcareous sediments, high silica indicators (e.g., opal-CT), moderate to high sedimentation rates, and sediments of Miocene age and older. Time and sediment type seem to be the most important factors in determining zeolite distributions in deep-sea sediments. It is also surprising that the temporal distribution of clinoptilolite is similar to that of marine cherts: both have significantly older occurrences in clayey than in carbonate sediments.

Houghton et al. (in press) investigated the distribution and chemistry of zeolites in three DSDP sites of the western North Atlantic: phillipsite is the dominant zeolite in volcanogenic and montmorillonite-rich sediments, while siliceous and feldspathic sediments are dominated by clinoptilolite.

In the hemipelagic facies of Site 397, we studied the relationship between the alteration of specific components (e.g., volcanic glass and biogenic opal) and zeolite authigenesis. We also determined the association of zeolites with other diagenetic minerals and the sequence of precipitation.

Apparently, there is the following distinct vertical succession of zeolites dependent on facies and burial depth (Figure 1): (a) Phillipsite only occurs in layers with altered volcanic glass in the carbonate-rich late Neogene sequence ( 310 to $800 \mathrm{~m}$ ) and in a single horizon at 970 meters. (b) Various zeolites (except clinoptilolite) are found in middle Miocene tuffs and tuffaceous sandstones ( 750 to $810 \mathrm{~m}$ ). (c) There is a widespread occurrence of clinoptilolite in lower Miocene pebbly mudstones ( 710 to $1300 \mathrm{~m}$ ).

Except for some more strongly silicified horizons above the Early Cretaceous/Miocene hiatus, the Neogene sediments contain much more zeolites than pure silica phases, such as opal-CT.

\section{Zeolites in Vitric Ashes and Volcaniclastic Sandstones}

The volcaniclastic sediments at Site 397 are of two types (Schmincke and von Rad, this volume): (1) ash fall deposits of silicic and alkalic composition, and (2) deposits of submarine volcaniclastic mass flows of basaltic composition. Table 1 shows all investigated vitric

TABLE 1

Alteration Stages of Vitric Ash and Tuff Layers and Formation of Authigenic Minerals at Site 397

\begin{tabular}{|c|c|c|c|}
\hline Sample No. & Alteration Stage & Sample No. & Alteration Stage \\
\hline $\begin{array}{l}\text { Cores } 2 \text { through } 33 \\
32-2,132 \mathrm{~cm} \\
37-4,130 \mathrm{~cm} \\
57-3,80 \mathrm{~cm} \\
57-4,140 \mathrm{~cm} \\
59, \mathrm{CC} \\
61-4,110 \mathrm{~cm} \\
73-1,100 \mathrm{~cm}\end{array}$ & $\begin{array}{l}\square \\
\square \\
\square\end{array}$ & $\begin{array}{l}75-1,90 \mathrm{~cm} \\
76-3,138 \mathrm{~cm} \\
76-4,28 \mathrm{~cm} \\
77-2,143 \mathrm{~cm} \\
77-3, \mathrm{CC} \\
85-3,80 \mathrm{~cm} \\
\text { A-6-2, } 22 \mathrm{~cm} \\
\text { A-23-3, } 30 \mathrm{~cm}\end{array}$ & ש \\
\hline - fresh & $\begin{array}{l}\text { slightly } \\
\text { altered }\end{array}$ & & $\begin{array}{l}\text { totally altered } \\
\text { (zeolite, mont- } \\
\text { morillonite etc. }\end{array}$ \\
\hline
\end{tabular}

Note: For mineral composition of altered vitreous sediments, see Table 4 in the Site Report (this volume). ashes with their general state of preservation. It is surprising to find fresh glass in ash layers between 550 and 695 meters (Cores 57 to 73) because extensive diagenetic alterations were already efficient at burial depths between 315 meters (Core 34) and 550 meters (Core 57). Since changes of chemical composition of these felsic glass shards were not noted, it is difficult to explain the strongly retarded diagenesis in these horizons.

Except for the last and oldest sample in Table 1, all diagenetically altered ash layers contain phillipsite which ranges up to 40 per cent of the sediment (maximum contents based on shipboard data). Under the microscope, the phillipsite crystals are frequently intergrown with pyrite and appear as individual elongated prisms (mostly up to $20 \mu \mathrm{m}$ long; Plate 3, Figure 5) or as spheres of radiating needles. Aggregates (up to 150 $\mu \phi)$ with atypical outlines also were noted. They either replace the calcareous-clayey matrix (Figure 3, Core 37 ) or grow in open foraminiferal chambers. The nucleation rates appear to be very high. In coarse-grained rocks with interparticle pores a distinct cavity-lining "rim cement" of phillipsite is developed (Plate 3, Figure 2).

Other undetermined zeolites are combined with phillipsite and more or less disintegrating glass particles. In a vitreous ash layer (Sample 397-76-4, $28 \mathrm{~cm}$ ) they form isolated inclusions in a few unaltered massive pumice shards (apparently no cement in vesicles, but possibly direct replacement of glass?), and also occur as stubby crystals in dissolved glass components.

The dominant minerals associated with phillipsite are calcite, terrigenous quartz, X-ray amorphous matter, montmorillonite, feldspar, and sometimes small amounts of opal-CT. Sediments which lack primary admixtures of volcanic glass contain no phillipsite (Figure 2 ). It is also missing in the immediate vicinity of ash layers. This suggests that the solutions, which originated after the disintegration of volcanic components, did not migrate outwards until the precipitation of authigenic phillipsite terminated.

The volcaniclastic sandstone sequence in the middle Miocene can be divided into three debris flow units: $\mathrm{V}-1, \mathrm{~V}-2$, and V-3 (Schmincke and von Rad, this volume). The sideromelane-rich hyaloclastite V-3 contains phillipsite, chabazite, and analcime (X-ray determination). These or similar zeolites (also optically identified in V-1) cement pores in the cryptocrystalline montmorillonite matrix (Plate 3, Figure 1). They also occur in vesicles of tachylitic basalt fragments (Plate 3, Figure 3 ) and in pores of dissolved pyroxene and olivine grains (Figure 3, Cores 84 and 85 ).

\section{Zeolites in Non-Volcanogenic Sediments}

The mainly clinoptilolite-bearing terrigenous (nonvolcanic) sediments of early to middle Miocene age at Site 397 were a rapidly deposited, mostly allochthonous sequence (Figure 1). Clinoptilolite does not prefer any specific lithofacies, but occurs in the more or less calcareous and dolomitic mudstones, as well as in marlstones, hemipelagic limestones, quartzose foramin- 
iferal sandstones, and dolomites. The clayey portion of these sediments is dominated by smectite (Chamley and d'Argoud, this volume) and X-ray amorphous matter (Rösch, personal communication). Admixtures of radiolarians are especially common in Cores 397A10 through 23.

Below 710 meters, calcite-cemented lithotypes change into a clinoptilolite/calcite association. Clinoptilolite is especially frequent in foraminiferal chambers from Cores 75 to 77 . Below 850 meters, the most conspicuous authigenic minerals are clinoptilolite, opalCT, pyrite, and dolomite rhombs, but many sediment pores are only partly cemented or not at all. In contrast to phillipsite, which is restricted to a few horizons, the clinoptilolite occurrences are more widespread (Figure 1 ), although the concentrations are significantly lower (Table 2). Other zeolites such as analcime and gmelinite (detected by $\mathrm{X}$-ray diffraction analysis) are rare (table 4, in Site 397 Report). Other zeolites observed under the SEM include spherical clusters $(10 \mu \phi)$, consisting of prismatic and acicular crystals and individual needles and fibers, could not be identified. They resemble erionite or mordenite (Mumpton and Ormsby, 1976).

The individual clinoptilolite prisms grow preferentially in foraminiferal chambers (Plate 3, Figure 4; Figure 3, Core 76). In some HC1-residues, clinoptilolite occurs as delicate casts of foraminiferal chambers including preserved wall pores (Plate 2, Figures 6 and 7; Figure 3, Core 76). The nucleation rate of clinoptilolite is lower than that of phillipsite and many foraminiferal chambers are only filled with a few prisms. This might also be due to less saturated clinoptilolite precipitating pore solutions during diagenesis.

In the sediments of Cores 397-75 to 77 , different types of cementation can be observed (Figure 2): the quartzose sandstones are only cemented by calcite because clinoptilolite is restricted to foraminiferal cham- bers. Some limestone beds contain only calcite-cemented foraminifers, whereas in others, the foraminifers are filled solely by clinoptilolite. Other limestones contain foraminifers filled with both calcite and clinoptilolite. This alternation may reflect differing contents of biogenic opal in the original sediments and indicate separated pore water levels.

At times, the percentage of clinoptilolite is positively correlated with the content of foraminifers (i.e., pore space) and/or radiolarian clasts (i.e., mobilization of silica by dissolution of the skeletons). A downward increase of preservation of radiolarian skeletons (opalCT) in Cores 397A-17 to 18 coincides with decreasing zeolite formation. Conversely, the content of clinoptilolite increases from Cores 397A-26 and 31 to 32 , because foraminifers become more frequent downhole. More or less constant admixtures of radiolarian casts are present in all cores.

The zeolite occurrences determined by the shipboard party at Site 398 (Figure 1) were only sporadically investigated. Because these sediments contain only trace amounts of volcanic material, but up to 30 per cent siliceous microfossils, the zeolites are probably dominated by clinoptilolite. For the following reasons, however, the vertical distribution pattern at Site 398, differs from that at Site 397 (details in Figure 1 and Table 3): (1) a more complete sedimentary record, (2) lower burial depth of synchronous sequences, and (3) different occurrences of biogenic opal.

The Barremian zeolite occurrences are buried under a water column of 3900 meters plus 1700 meters of sediments; this is the equivalent of about 3000 meters burial depth on land. These minerals might represent the "deepest" zeolites discovered by the DSDP up to now.

At Site 398 , a roughly positive correlation between the amounts of zeolites and siliceous organisms also was detected. This is not true for the section between

TABLE 2

Comparison of Zeolite Formation in Volcanogenic and Non-Volcanogenic Facies, Site 397

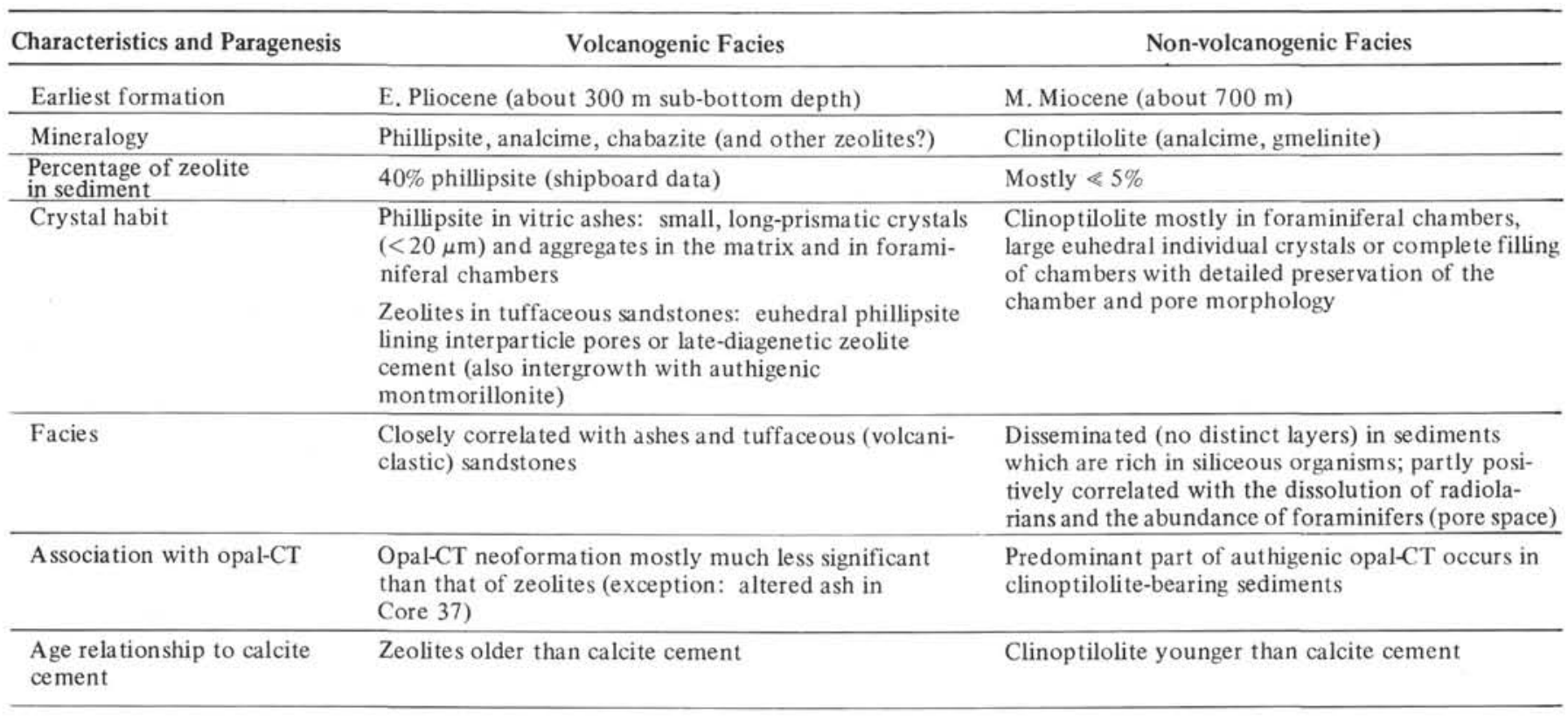


TABLE 3

Comparison of Zeolite Occurrences at Site 397 (upper rise off Cape Bojader) and Site 398 (Vigo Seamount)

\begin{tabular}{|c|c|c|c|}
\hline & & Site 397 & Site 398 \\
\hline \multicolumn{2}{|c|}{$\begin{array}{l}\text { Depth range of } \\
\text { zeolites }(\mathrm{m})\end{array}$} & 300 to 1300 & 600 to 1700 \\
\hline \multicolumn{2}{|c|}{ Maxima of zeolites } & Pliocene, Miocene & $\begin{array}{l}\text { Eocene, Paleo- } \\
\text { cene, Campanian, } \\
\text { Cenomanian, Albian }\end{array}$ \\
\hline \multicolumn{2}{|c|}{ Minimum age } & Pliocene & $\begin{array}{l}\text { Eocene/ } \\
\text { Oligocene }\end{array}$ \\
\hline \multicolumn{2}{|c|}{ Maximum age } & $\begin{array}{l}\text { Miocene? (erosion } \\
\text { of Paleogene and } \\
\text { older sediments) }\end{array}$ & Hauterivian \\
\hline \multicolumn{2}{|c|}{ Derivation of silica } & $\begin{array}{l}\text { "Biogenic" and } \\
\text { "volcanigenic" }\end{array}$ & $\begin{array}{l}\text { Probably only } \\
\text { "biogenic" }\end{array}$ \\
\hline \multirow[t]{3}{*}{$\begin{array}{l}\text { Comments } \\
\text { on } \\
\text { differences }\end{array}$} & $\begin{array}{l}\text { minimum } \\
\text { age }\end{array}$ & $\begin{array}{l}\text { Young phillipsite } \\
\text { occurrences at com- } \\
\text { paratively shallow } \\
\text { burial depths because } \\
\text { of alteration of dia- } \\
\text { genetically unstable } \\
\text { ashes }\end{array}$ & $\begin{array}{l}\text { No ashes in } \\
\text { young sediments }\end{array}$ \\
\hline & $\begin{array}{l}\text { burial } \\
\text { depth }\end{array}$ & $\begin{array}{l}\text { Miocene: } 400 \text { to } \\
1300 \mathrm{~m} \text { sub-bottom } \\
\text { depth; below } 700 \mathrm{~m} \text {, } \\
\text { clinoptilolite in sedi- } \\
\text { ments with siliceous } \\
\text { organisms }\end{array}$ & $\begin{array}{l}\text { Miocene: only } \\
300 \text { to } 500 \mathrm{~m} \\
\text { sub-bottom } \\
\text { depth; therefore, } \\
\text { clinoptilolite } \\
\text { only in pre- } \\
\text { Miocene } \\
\text { sediments }\end{array}$ \\
\hline & $\begin{array}{l}\text { availability } \\
\text { of silica } \\
\text { source }\end{array}$ & $\begin{array}{l}\text { Paleogene to Upper } \\
\text { Cretaceous zeolites } \\
\text { missing because of } \\
\text { hiatus; Lower Creta- } \\
\text { ceous devoid of } \\
\text { zeolites because of } \\
\text { lack of dissolvable } \\
\text { silica source }\end{array}$ & $\begin{array}{l}\text { Formation of } \\
\text { Cretaceous zeo- } \\
\text { lites possible be- } \\
\text { cause of the } \\
\text { presence of sili- } \\
\text { ceous organisms }\end{array}$ \\
\hline
\end{tabular}

Note: Site 397 data based on this investigation; Site 398 from shipboard data.

450 and 600 meters sub-bottom, probably because unfavorable diagenetic conditions (e.g., relatively low burial depth?) at this level did not promote the formation of clinoptilolite. Moreover, the complete dissolution of zeolites cannot be excluded. Corroded clinoptilolite (Plate 3, Figure 6) and etched radiolarians and sponge spicules in Cores 398D-22 and 23 indicate silica-undersaturated pore waters in the upper Eocene sediments. No opal maximum was observed in the mid-Cretaceous sediments, which could explain the abundance of zeolites at this level (Figure 1); a strong dissolution of siliceous microfossils, however, may have been overlooked.

\section{Authigenic Phyllosilicates}

According to Chamley and d'Argoud (this volume), the smectite-rich lower and middle Miocene sediments of Site 397 are due to the erosion of soils in Northwest Africa, where smectite originated in a warm climate with rainy seasons. In addition to this montmorillonite, which is obviously of detrital origin, there are a few examples of authigenic phyllosilicates.
Thin-section observations combined with X-ray diffraction results indicate a predominantly diagenetic nature for smectite in volcanic ashes, tuffs, and tuffaceous sandstones. We identified well-crystallized seams and spheres of phyllosilicates (Figure 3, Cores 84 and 85) in the interparticle pore space. In the non-volcanogenic facies, however, there are examples for an in-situ growth and cementation of layer silicates. Smectite occurs inside of calcitic rim cement in foraminiferal chambers (Figure 3, Core 75). It forms detailed casts of chambers and wall pores (Plate 3, Figures 7 and 8), or replaces calcitic echinoid spines (Figure 3, Core 75).

An extinction of the matrix parallel to the bedding in thin sections can be observed in various degrees in the lower Miocene and Hauterivian clayey facies of Site 397 (X-ray data table 4 of Site 397 Report). The cause of this "aggregate polarization" is not completely understood. The mass extinction occurs in opal-CT/ palygorskite/sepiolite sediments or in clayey porcelanites (Keene, 1976; von Rad et al., 1978) we well as in sediments with various composition of clay minerals but devoid of opal-CT (Site 397). Therefore, this phenomenon is not only caused by a potential precipitation of opal-CT (and layer silicates) under directed stress, but also by compaction of detrital clay minerals.

\section{AGE RELATIONSHIP BETWEEN AUTHIGENIC MINERALS}

According to the spatial arrangement of various authigenic minerals in sediment pores, a chronological sequence of precipitation can be inferred from thin-section and SEM investigations (Figure 4). Moreover, the vertical distribution of such minerals in the sediment column provides additional clues for the determination of the age relationships. The replacement of siliceous skeletons by pyrite and the genesis of phillipsite in volcanic ashes occur quite early and are relatively fast diagenetic processes (Figures 3 and 4).

In general, an enhanced authigenesis of opal-CT, zeolites, and phyllosilicates is detectable in the volcanogenic sediments of Site 397 (Figure 4). The zeolitic minerals represent an intermediate diagenetic stage in the tuffaceous sandstones of Site 397 , because authigenic phyllosilicates are earlier crystallized phases, while calcite closes the central pores as a final cement (Figure 3, Cores 84 and 85). Similar observations were reported by Matter and Gardner (1975) from Eocene biogenous volcanic sandstones of the Emperor Seamounts in the Pacific. According to Hay (1966), the alteration of volcanic glass to montmorillonite is an important step toward initiating the zeolite formation.

In contrast to the "volcanogenic" zeolites, clinoptilolite is never overgrown by calcite. Instead, this zeolite grows on epitaxial calcite overgrowths of foraminiferal tests (calcite cement A) or on large calcite rhombohedra (cement B; Figure 3, Core 76) and thus represents the last cement generation in foraminiferal chambers. Notably, at a sub-bottom depth of about 750 meters, 


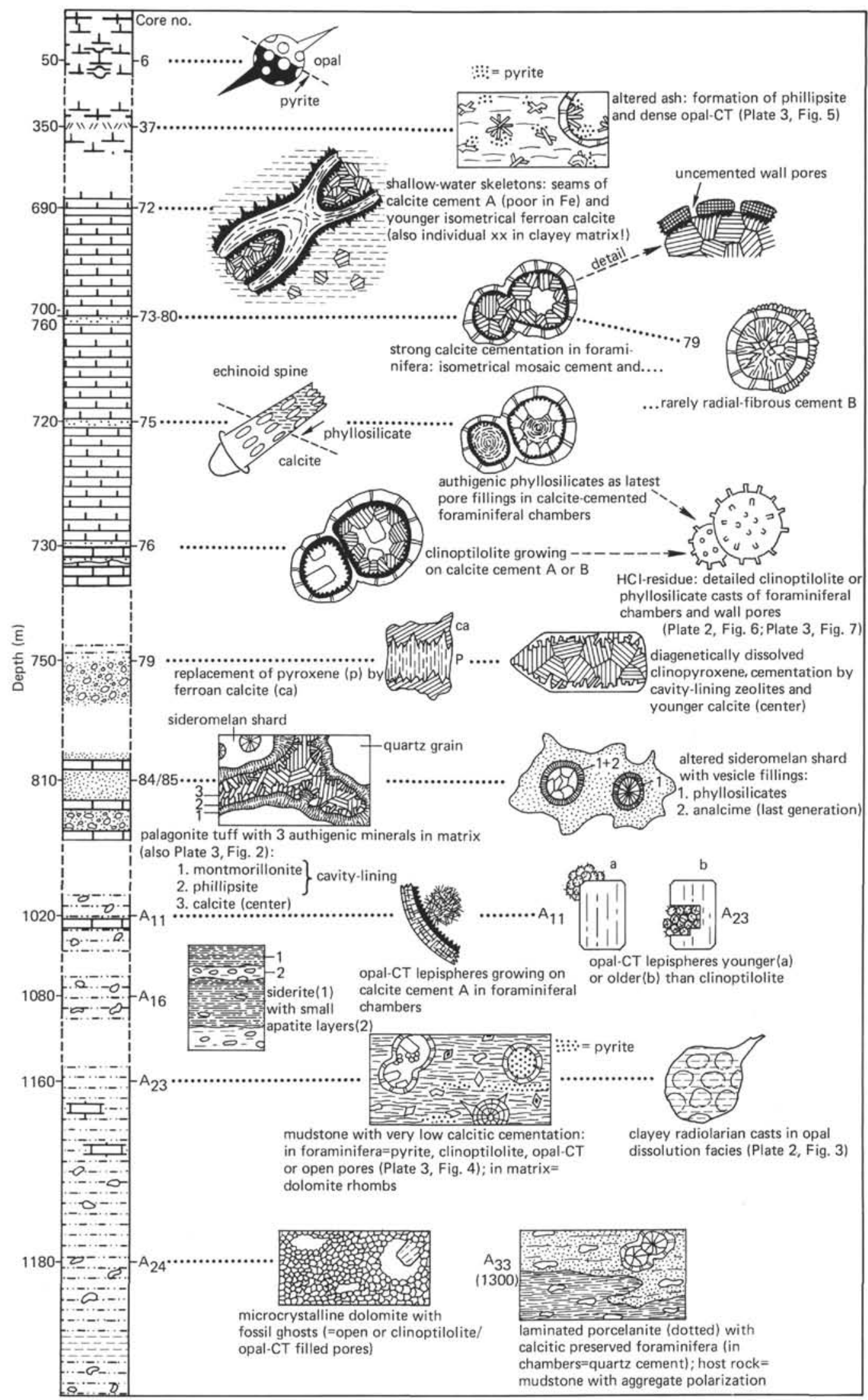

Figure 3. Schematic diagram showing diagenetic phenomena in lower Miocene to Quaternary calcareous sediments, claystones, sandstones, ashes, and tuffaceous sandstones of Site 397. 


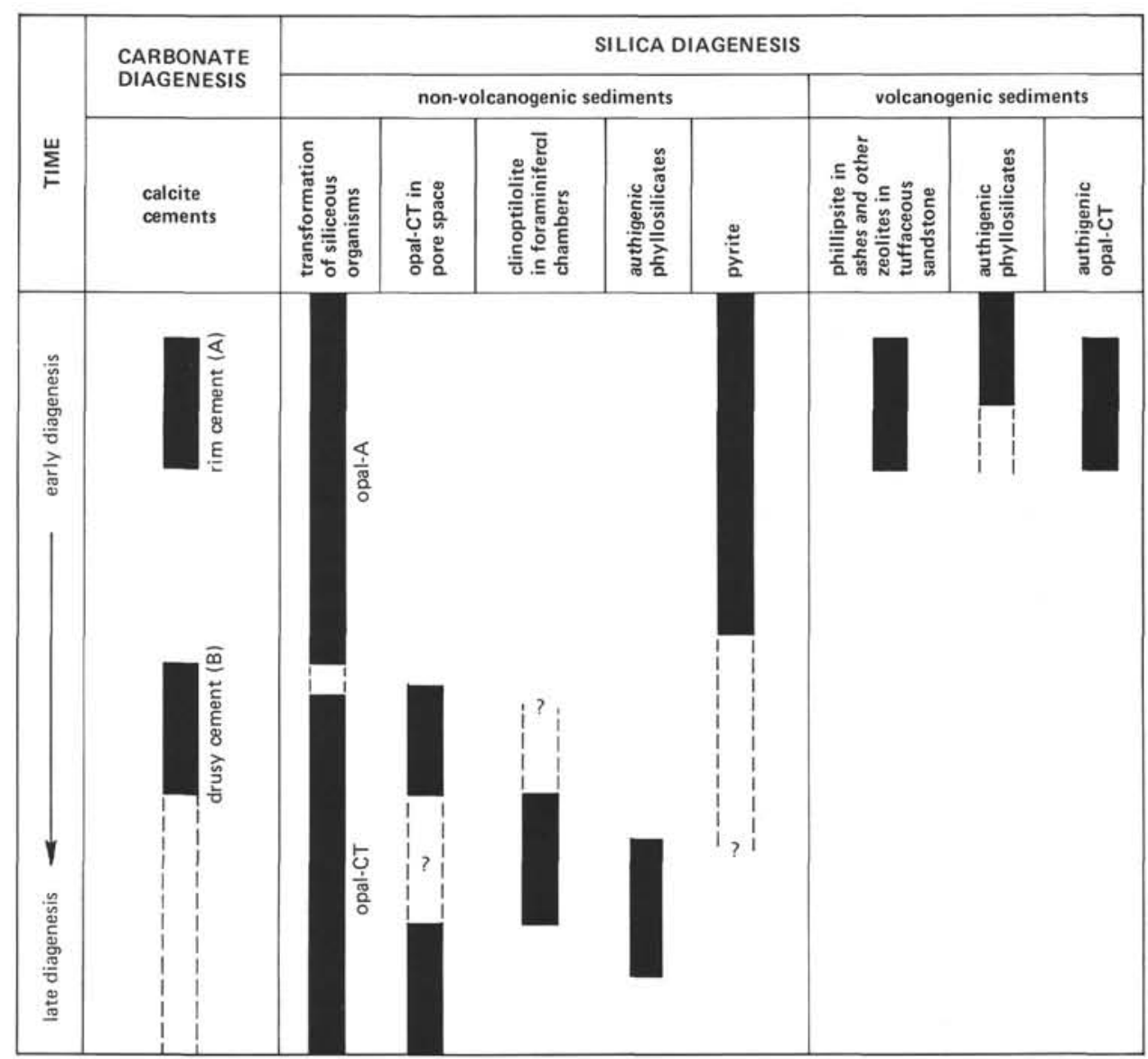

Figure 4. Age relationship of different authigenic minerals at Sites 397 and 398. Within volcanogenic sediments, authigenic silicates are always significantly younger than in non-volcanogenic facies. Clinoptilolite which originated from biogenic silica was precipitated later than late-diagenetic calcite cement. In layers with reduced calcite cementation, the clinoptilolite might be formed at an earlier diagenetic state (synchronous with calcite cement of adjacent horizons?). The zeolites of tuffs and tuffaceous sandstones are formed earlier than drusy calcite cement.

clinoptilolite was observed growing on different types of calcite cement. This might be the result of the following diagenetic processes: (1) Because of reduced calcite cementation, there is a time lag between the formation of the early diagenetic calcite and zeolites. This means that the clinoptilolite growing on the first-generation calcite cement would be age equivalent to similar zeolites nearby which have precipitated after secondgeneration calcite. (2) Clinoptilolite growing on a firstgeneration calcite can also be precipitated at the same time as calcite cement B in nearby layers, if the pore water levels are separated.

These processes might explain the presence of two age-different clinoptilolite generations.

Indicated by SEM observations, opal-CT lepispheres crystallize either before or after the precipitation of clinoptilolite (Figure 3, Core 397A-11). At Site 397, the precipitation of both authigenic minerals is approximately synchronous (i.e., in 13-m.y.-old sediments) with the in situ transformation of biogenous opal-A into opal-CT. At Site 398, clinoptilolite originates before this transformation takes place.

\section{DISCUSSION AND CONCLUSIONS}

\section{General Diagenetic Trends}

The development of silica diagenesis at Site 397 is essentially predetermined by the original content of skeletal opal and/or volcanic components, both of which are potential parent materials for the neoformation of authigenic silica and silicates. In general, the transformation is dependent on age and overburden. However, the rate of these processes varies and is also influenced by the amount, kind, and stability of the primary silica-contributing components; the lithofacies and permeability of the host sediments; the sedimentation rates; and the pore water chemistry.

At Site 397, the earliest significant effects of diagenesis can be detected in the volcanic ash layers below 300 meters sub-bottom, as shown by the authigenesis of phillipsite, montmorillonite, and some opal-CT. A distinct "diagenetic jump" occurs at about 700 meters, coinciding with the transition of the lower Neogene allochthonous to the overlying upper Neogene autochthonous lithofacies; this occurs in a section deposited at 
comparatively low sedimentation rates (about 20 $\mathrm{m} / \mathrm{m}$.y.) and containing two hiatuses (at 680 and 740 $\mathrm{m})$. The enhanced degree of diagenesis is indicated by intensive calcite cementation (chalk-limestone transition), the first occurrences of clinoptilolite and opal-CT lepispheres in pores, and the nearly contemporaneous in-situ transformation of amorphous siliceous skeletons into crystalline opal-CT. Whereas the $\mathrm{CaCO}_{3}$ cementation decreases below 830 meters, the precipitation of clinoptilolite and opal-CT increases down to a depth of 1300 meters. In the Hauterivian sequence, however, authigenic silicates are completely missing.

\section{Authigenic and Biogenic Silica}

At Site 397, the formation of authigenic silica (opalCT) is much less significant than the genesis of zeolites. Opal-CT lepispheres are associated in small amounts with clinoptilolite between 700 and 1300 meters. Silicified (porcelaneous) mudstones and porcelanites developed only in the deepest part of the early Miocene. This is due to a maximum of siliceous organisms in this section (earliest Miocene upwelling?, see Site Report). The siliceous nannofossil oozes of Quaternary and Pliocene age (late Pliocene-Quaternary upwelling) are largely unaltered because of insufficient burial depth.

Because of the dominantly allochthonous nature of the lower Miocene sediments and the missing postHauterivian to earliest Miocene record at Site 397, it is necessary to decide whether the porcelanites and cherts found in the lower Miocene section are autochthonous or derived from pre-Miocene outcrops. The mature quartz-cherts found at a depth of about 900 meters are allochthonous pebbles of perhaps Eocene of Late Cretaceous origin (von Rad et al., 1978). The fabric of the porcelaneous mudstones and porcelanites in the lowermost Miocene, however, is so similar to the autochthonous rock that an in-situ origin is highly probable. The widespread authigenesis of accessory opal-CT in these mudstones further supports the assumption of an autochthonous nature for these porcelanites. At Site 397 , two factors may also have caused an accelerated rate of silica diagenesis: (1) comparatively high heat flow $(4 \% 100 \mathrm{~m}$ : see Site Report, this volume), (2) the opal-CT formation is enhanced by the precipitation of nuclei with magnesium hydroxide as an important component (Kastner et al., 1977). The clay minerals, which also incorporate $\mathrm{Mg}$ ions, compete with opal-CT formation and might reduce its formation rate. The sporadic dolomite occurrences in the lower Miocene of Site 397 suggest an excess of magnesium which might favor the nucleation of opal-CT.

Drilling results in nearby areas off northwest Africa also indicate that the youngest porcelanites occur in lower Miocene sediments; e.g., at 600 meters at Site 139 (von Rad and Rösch, 1974) and at only 220 meters at Site 370 (von Rad et al., 1978). In all cases, the clayey host rocks contain only small amounts of calcite. According to an experimental study of Kastner et al. (1977), however, the transformation rate of opal-A to opal-CT should be much higher in calcareous than in clay-rich sediments. Therefore, it is surprising that the youngest (lower Miocene) porcelanites off northwest
Africa are associated with clayey sediments. Possibly 10 to 20 per cent $\mathrm{CaCO}$ - is sufficient to initiate this diagenetic process.

\section{Zeolites}

The zeolite occurrences at Site 397 show a relatively simple distribution pattern which is influenced mainly by composition and age or by overburden. Disseminated clinoptilolite formed in a wide range of host sediments, but especially radiolarian-bearing limestones, marlstones, and mudstones ( 700 to $1300 \mathrm{~m}$ ). In addition, clinoptilolite prefers intrafossil pore space so that a clear relationship exists between clinoptilolite occurrences and foraminiferal content.

Phillipsite with a lower $\mathrm{Si} / \mathrm{Al}$ ratio is only associated with altered volcanic glass ( 310 to $800 \mathrm{~m}$ ); it is usually younger than clinoptilolite and restricted to distinct ash layers.

The abundance of both zeolites depends on the degree of decay of the parent material. Fresh glass (above $300 \mathrm{~m}$ and between 550 and $700 \mathrm{~m}$ ) is negatively correlated with phillipsite. Siliceous organisms with preserved skeletons (e.g., between 1080 and 1100 $\mathrm{m})$ show the same negative correlation for clinoptilolite.

Clinoptilolite is the dominant zeolite of Site 398. However, it does not occur above the Eocene/Oligocene boundary (about $600 \mathrm{~m}$ ), possibly due to the shallower burial and lower heat flow conditions of this site.

The occurrences of phillipsite in distinct thin layers suggest a restricted flow of pore solutions during the crystallization process. The high nucleation rate of this zeolite and a probable fast growth rate provided an immediate incorporation of the ions present in the pore waters.

Phillipsite is conspicuously different from clinoptilolite in several aspects: (a) The percentages are frequently higher (due to higher admixtures of the parent material volcanic glass). (b) There is a genetic relationship with authigenic montmorillonite. (c) It is rarely associated with opal-CT. (d) Phillipsite represents an intermediate stage of diagenesis after montmorillonite and younger calcite cement; whereas clinoptilolite represents the final phase after calcite cement.

\section{Interrelationship of Carbonate, Authigenic Silica, and Silicates}

The silica-rich clinoptilolite can form either during an increase of the silica concentration in the pore waters before opal-CT or during a decrease of this concentration after opal-CT. The influence of the dissolved cations is also important. The crystallization sequence clinoptilolite/opal-CT could be explained as follows: after the consumption of much of the alkali and alkaline earth ions for the formation of clinoptilolite, only pure silica can precipitate, if additional dissolved $\mathrm{Si}(\mathrm{OH})_{4}$ is present. It is possible that the mineralogical succession also depends on the rate of the process of silica-saturation. During rapid dissolution of opaline skeletons, the precipitation sequence opal/CT/clinoptilolite can be expected. 
At Site 397, montmorillonite is the dominant clay mineral in the clinoptilolite-bearing lower to middle Miocene sequence, but no causal relationship can be seen. There are no indications of the conversion of smectite to illite which could enhance the $\mathrm{Si} / \mathrm{Al}$ ratio in the pore waters (Stonecipher, 1976) and promote the formation of clinoptilolite.

In the transitional limestone/mudstone facies of Site 397 , clinoptilolite originates directly after a stage of intermediate to late diagenetic and interrupted calcite cementation. The precipitation of this precursor mineral reduced the carbonate activity in the pore solutions and favored the subsequent formation of clinoptilolite. Within the lower Miocene mudstones, the original carbonate activities were significantly lower. This allowed only the nucleation of small amounts of secondary calcite before the crystallization of zeolite.

\section{ACKNOWLEDGMENTS}

I am especially grateful to H. Rösch (Hannover), who analyzed 100 samples with X-ray diffraction (see Table D-3a in Site chapter). E. Knickrehm (Hannover) operated the Autoscan. U. von Rad (Hannover) stimulated this study, reviewed the manuscript, suggested several improvements, and helped with the translation. L. Diester-Haass and M. Sarnthein (Kiel) kindly provided some of their own samples.

This study was generously supported by the Deutsche Forschungsgemeinschaft Grant $\mathrm{Ra} 191 / 6+7$ on silica diagenesis in continental margin sediments to $\mathrm{U}$. von Rad and H. Rösch:

\section{REFERENCES}

Flörke, O. W., Hollmann, R., von Rad, U., and Rösch, H. 1976. Intergrowth and twinning in opal-CT lepispheres, Contrib. Mineral. Petrol., 58, p. 235-242.

Goll, R. M. and Bjфrklund, K. R., 1972. Radiolaria in surface sediments of the North Atlantic Ocean, Micropaleontolgy, v. 17 , p. $434-454$.

, 1974. Radiolaria in surface sediments of the South Atlantic, Micropaleontology, v. 20, p. 38-75.

Hay, R. L., 1966. Zeolites and zeolitic reactions in sedimentary rocks, Geol. Soc. Am., Spec. Pap., v. 85, p. 1-130.

Heath, G. R., 1974. Dissolved silica and deep-sea sediments, in W. W. Hay (Ed.), Studies in Paleo-Oceanography, Soc. Econ. Paleontol. Mineral., Spec. Publ., v. 20, p. 77-93.

Houghton, R. L., Rothe, P., and Galehouse, J. S., in press, Distribution and chemistry of phillipsite, clinoptilolite and associated zeolites at DSDP Sites 382, 385 and 386 in the western North Atlantic. In Tucholke, B., Vogt, P., et al., Initial Reports of the Deep Sea Drilling Project, v. 43: Washington (U.S. Government Printing Office).

Hurd, D. C. 1973. Interactions of biogenic opal, sediment and seawater in the central equatorial Pacific, Geochim. Cosmochim. Acta, v. 37, p. 2257-2282.

Hurd, D. C. and Theyer, F., in press. Changes in the physical and chemical properties of biogenic silica from the central equatorial Pacific: Part II Refractive index, density and water content of acid-cleaned samples, Am. Chem. Soc., Advances in Chemistry Series.
Johnson, T. C., 1974. The dissolution of siliceous microfossils in surface sediments of the eastern tropical Pacific, DeepSea Research, v. 21, p. 851-864.

, 1976. Biogenic opal preservation in pelagic sediments of a small area in the eastern tropical Pacific, Geol. Soc. Am. Bull., v. 87 , p. 1273-1282.

Jones, J. B. and Segnit, E. R., 1971. The nature of opal, I.Nomenclature and constituent phases, J. Geol. Soc. Australia, v. 18 . p. $57-68$.

Kastner, M., Keene, J. B., and Gieskes, J. M., 1977. Diagenesis of siliceous oozes. I. Chemical controls on the rate of opal-A to opal-CT transformation-an experimental study, Geochim. Cosmochim. Acta, v. 41, p. 1041-1059.

Keene, J. B. 1975. Cherts and porcelanites from the North Pacific, Deep Sea Drilling Project Leg 32. In Larson, R. L., Moberly, R., et al., Initial Reports of the Deep Sea Drilling Project, v. 32, Washington (U.S. Government Printing Office), p. 429-507.

,1976. The distribution, mineralogy and petrography of biogenic and authigenic silica from the Pacific Basin, $\mathrm{Ph}$. D. Thesis, San Diego,

Matter, A. and Gardner, J. V., 1975. Carbonate diagenesis at Site 308 Koko Guyot. In Larson, R. L., Moberly, R.. et al., Initial Reports of the Deep Sea Drilling Project, v. 32: Washington (U.S. Government Printing Office), p. 521535

Mizutani, S., 1977. Progressive ordering of cristobalitic silica in the early stage of diagenesis, Contrib. Mineral. Petrol. v. 61, p. $129-140$

Mumpton, F. A. and Ormsby, W. C., 1976. Morphology of zeolites in sedimentary rocks by scanning electron microscopy, Clays and clay minerales, v. 24, p. 1-23

Riech, V. and von Rad, U., in press. Eocene porcelanites and Early Cretaceous cherts from the western North Atlantic Basin. In Tucholke, B., Vogt, P., et al., Initial Reports of the Deep Sea Drilling Project, v. 43: Washington (U.S. Government Printing Office).

Schlanger, S. O. and Douglas, R. G., 1974. The pelagic oozechalk-limestone transition and its implications for marine stratigraphy. In Hsü, K. J. and Jenkyns, H. C. (Eds.), Pelagic sediments: on land and under the sea: Spec. Publ. Int. Assoc. Sediment., v. 1, p. 117-148.

Schrader, H.-J., 1972. Kieselsäure-Skelette in Sedimenten des ibero- marok- kanischen Kontinentalrandes und angrenzender TiefseeEbenen. Meteor-Forsch.-Ergebnisse, C, v. 8 , p. 10-36.

Stein, C. L. and Kirkpatrick, R. J., 1976. Experimental porcelanite recrystallization kinetics: A nucleation and growth model, J. Sediment. Petrol., v. 46, p. 430-435.

Stonecipher, S. A., 1976. Origin, distribution and diagenesis of phillipsite and clinoptilolite in deep-sea sediments, Chem. Geol., v. 17, p. 307-318.

von Rad, U. and Rösch, H., 1974. Petrography and diagenesis of deep sea cherts from the central Atlantic. In Hsü, K. J. and Jenkyns, H. C. (Eds.), Pelagic sediments: on land and under the sea: Spec. Publ. Int. Assoc. Sediment., v. 1, p. 327-347.

von Rad, U., Riech, V., and Rösch, H., 1978. Silica diagenesis in continental margin sediments off Northwest Africa. In Lancelot, Y., Seibold, E., et al., Initial Reports of the Deep Sea Drilling Project, v. 41: Washington (U. S. Government Printing Office), p. 879-905. 


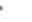


PLATE 1

Scanning electron photomicrographs of opal-A organisms.

Figures 1, 2 Radiolarian with excellent preservation of skeleton. Quaternary. Depth of burial: 80 meters. (Sample 397-9-1, 110-114 cm; SEM 902/3 and 2).

Figure 3 Upper Eocene sponge spicule (opal-A) with solution pits. Burial depth: 615 meters. (Sample 398D-22-24, 23-25 cm; SEM 903/1).

Figure 4 Upper Eocene sponge spicule consisting of altered granular opal-A. (Sample 398D-23-2, 32$33 \mathrm{~cm}$; SEM 900/10).

Figures 5, 6 Opal-A preserved radiolarian with solution pits. Same sample as Figure 4 (SEM 903/8 and 7). 
PLATE 1
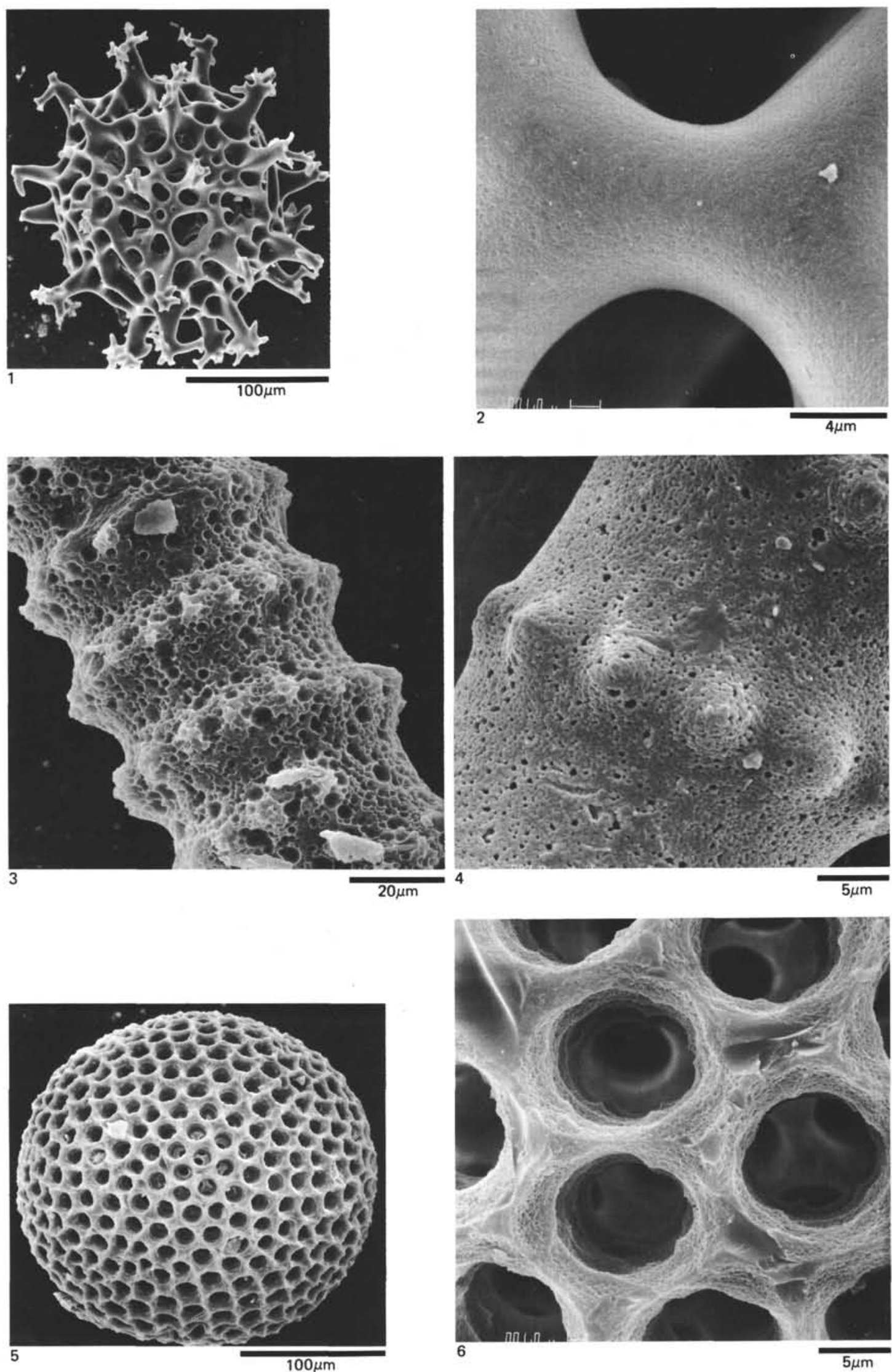
PLATE 2

SEM photomicrographs of radiolarians, their fillings, and zeolitic casts of foraminifers.

Figures 1, 2 Radiolarian skeleton, probably transformed to opal-CT(?) with filling of amorphous silicates and montmorillonite. Early Miocene, burial depth 1160 meters. (Sample 397A-23-3, 8-10 cm; SEM 905/1, 904/11).

Figures 3, 4 Radiolarian cast consisting of amorphous silicates and montmorillonite. Where the siliceous skeleton has been dissolved, opal-CT blades and lepispheres (Figure 4) were precipitated. Same sample as Figure 1 (SEM 904/8 and 7).

Figure 5 Framboidal pyrite and opal-CT filling a dissolved radiolarian. Early Miocene. (Sample 397A-33-1, 55-56 cm; ISEM 905/2).

Figures 6,7 Clinoptilolite filling a foraminiferal chamber which was dissolved by HCI. The cylinder-like "spines" on the clinoptilolite are casts of the pores in the foraminiferal chamber wall. If the chambers and wall pores are filled completely, the zeolitic crystal habit disappears. Middle Miocene, $740 \mathrm{~m}$ burial depth. (Sample 397-77-3, CC; SEM $924 / 12$ and 8 ). 
PLATE 2

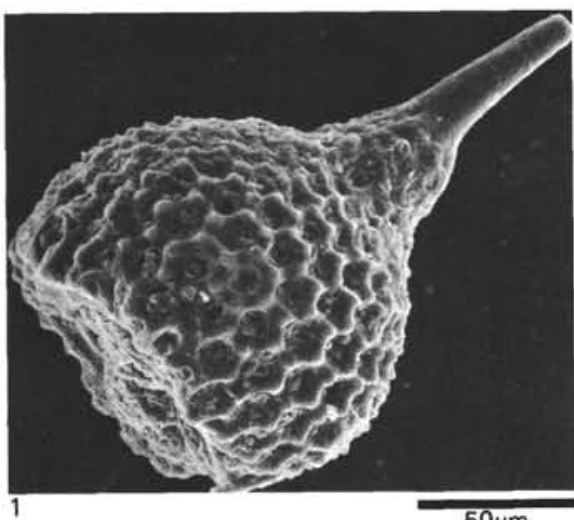

$50 \mu \mathrm{m}$
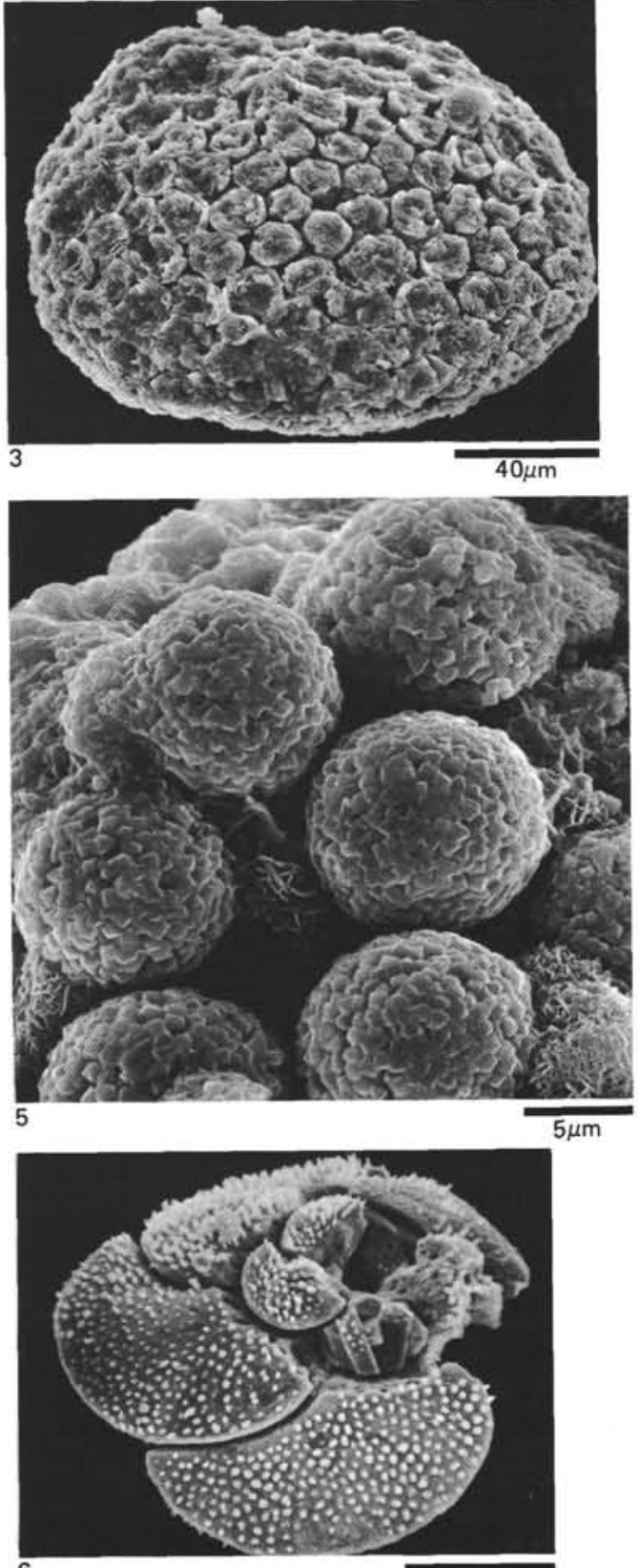

$200 \mu \mathrm{m}$
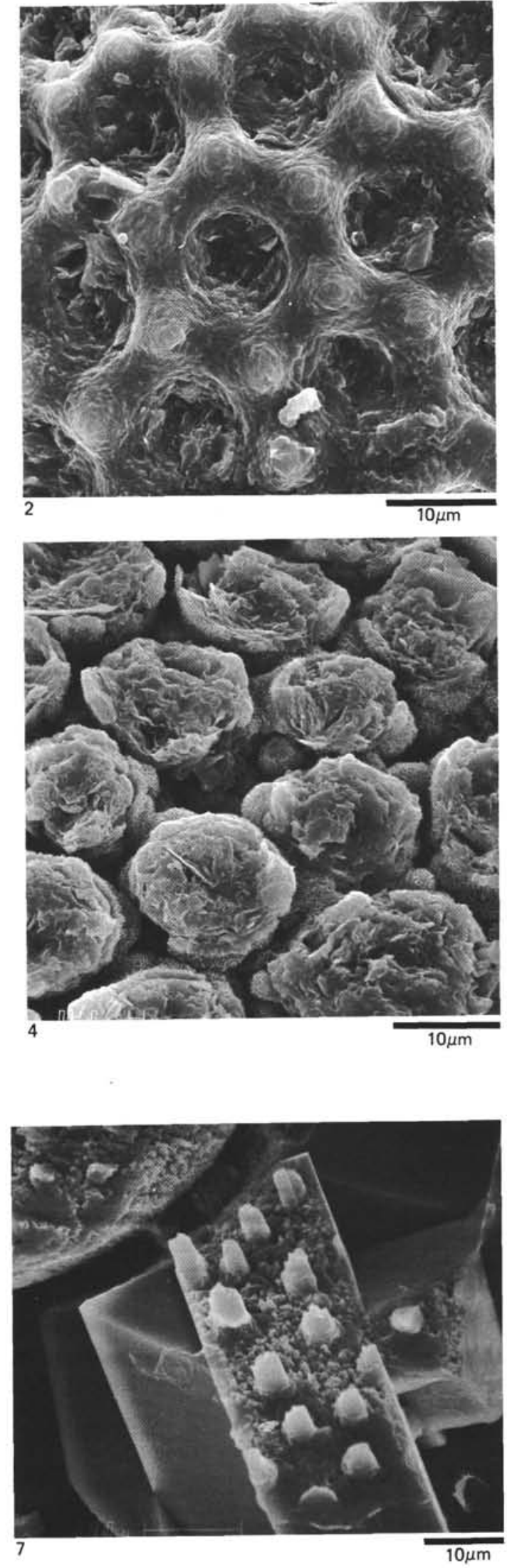
PLATE 3

Thin-section and SEM photos showing silicatic pore fillings of Pliocene, middle, and lower Miocene Site 397 sediments.

Eocene zeolites of Site 398.

Figures 1-3 Authigenesis of zeolites in the volcaniclastic facies (middle Miocene) combined with the neoformation of montmorillonite (dark areas in photos).

1. Blocky zeolites in interparticle pores of a lapillistone. Central pore space is empty (Sample 397-79-4, 37-40 cm; photo 50/2A).

2. Long-prismatic zeolite crystals as first and calcite cement (in center) as last pore filling generation in a quartz-rich altered palagonite tuff. (Sample 397-85-3, 77-80 cm; photo 50/ 4A).

3. Several cement generations in vesicles of tachylitic basalt fragment: fibrous or bladed silicates grading into zeolites in the vesicle center. Volcaniclastic sandstone. (Sample 397-79-3, 91-93 cm; photo 49/29).

Figure 4 In the clayey lower Miocene section Hole 397A, authigenic silicates (Figures $4,7,8$ ) replace the calcite cementation, typical of the upper section of the hole. In this figure, opal-CT lepispheres and blocky clinoptilolite are filling a foraminiferal chamber. Calcareous mudstone and radiolarian dissolution facies (see also Plate 2, Figures 3 and 4). (Sample 397A-23-3, 8-10 cm; SEM 905/4).

Figure 5

Pliocene phillipsite growing in a 2-mm-thick layer of vitric ash (zeolitic foraminiferal nannofossil ooze). Due to strongly oversaturated pore solutions the rate of nucleation is much higher than in Figure 4 (Sample 397-34-2, $133 \mathrm{~cm}$; SEM 906/10).

Figure 6 Diagenetically corroded zeolites in an opal-A preserved radiolarian. Same facies and Eocene age as corroded siliceous organisms shown in Plate 1, Figures 3,6. (Sample 398D-22-4, 23$25 \mathrm{~cm}$; SEM 899/6).

Figures 7, 8 Authigenetic intra-foraminiferal formation of montmorillonite (proven by XRD analysis) within a foraminiferal arenite containing some volcaniclastic components. The complete filling of the delicate wall pores by smectite suggests genuine cementation of the cavities rather then mechanical introduction of clay minerals during sedimentation. This facies occurs at the level of the volcaniclastic sandstones of Hole 397. Apparently, montmorillonite is a frequent alteration product of volcanogenic sediments. (Sample 397A-2-2, 24-29 cm; SEM 927/3 and 1). 
PLATE 3
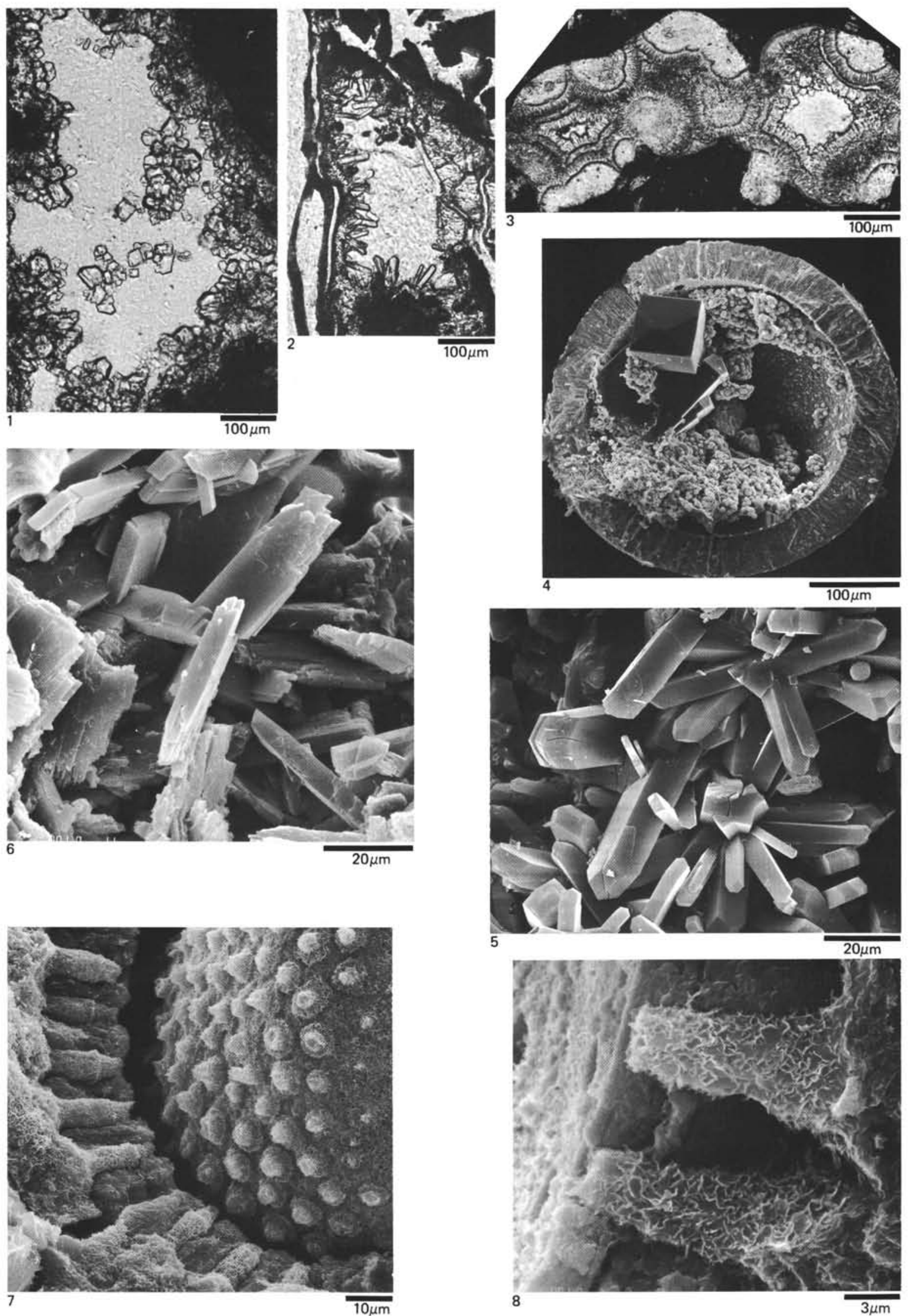